\title{
Effect of organic and inorganic farming conditions on seed storage proteins in soybean based cropping system
}

\author{
P. Kaur ${ }^{1 *}$, S. Sharma ${ }^{1}$, P. Kumar ${ }^{1}$ and G. Singh ${ }^{2}$ \\ ${ }^{1}$ Department of Biochemistry, Punjab Agricultural University, Ludhiana -141004 (Punjab), INDIA \\ ${ }^{2}$ Department of Plant Breeding and Genetics, Punjab Agricultural University, Ludhiana -141004 (Punjab), INDIA \\ *Corresponding author. E-mail: kaur.prabhdeep74@yahoo.com
}

Received: December 24, 2015; Revised received: September 30, 2015; Accepted: October 30, 2015

\begin{abstract}
A field experiment was conducted during rainy (kharif) and winter (rabi) seasons of 2011-13 to evaluate the effect of application of farm yard manure (FYM), recommended doses of fertilizers (RDF) and their combination on storage protein quality of soybean [Glycine max (L.) Merr.], chickpea (Cicer arietinum L.) and wheat (Triticum aestivum L.) in soybean based cropping system in Punjab. Densitometric analysis of chromatograms revealed significant variations in relative densities of $\alpha^{\prime}$ subunit of $\beta$-conglycinin protein in soybean in year 2011 and $\alpha$ subunit of legumins in chickpea among different treatments whereas other subunits of glycinin and $\beta$-conglycinin in soybean and legumins and vicillins in chickpea did not vary significantly. Maximum value of $11 \mathrm{~S} / 7 \mathrm{~S}$ ratio was observed in treatment with FYM @ 10t ha ${ }^{-1}$ and FYM @ 10t ha ${ }^{-1}+100 \%$ RDF in soybean seeds in year 2011 and 2012 respectively and with RDF in chickpea. In wheat, the relative quantity of 55.7, 48.8 and between 11-13 kDa bands increased significantly in combined treatment of organic or inorganic fertilizer than their individual treatments, whereas relative quantity of $40.7 \mathrm{kDa}$ band was significantly low in FYM @10t ha ${ }^{-1}+100 \%$ RDF treatment as compared to other treatments. Combined treatments of organic and inorganic fertilizer resulted in presence of additional bands corresponding to 61.4 and $22.5 \mathrm{kDa}$ and disappearance of subunit band corresponding to $16.4 \mathrm{kDa}$ in wheat grains. It is concluded that combined organic and inorganic treatments did not change major storage protein fractions and can be used to improve fertilizer management practices.
\end{abstract}

Keywords: Chickpea, Fertilizer, Organic, Protein, Soybean, Wheat

\section{INTRODUCTION}

Legumes and cereals are important dietary protein sources throughout the world. The globular $11 \mathrm{~S}$ glycinin and $7 \mathrm{~S} \beta$-conglycinin are major soybean storage proteins which, together account for about $70 \%$ of the total seed protein. In chickpea, major storage proteins are legumins and vicillins. Wheat proteins are divided into four categories: albumin, globulin, gliadin and glutenin according to their solubility in water, dilute salt, ethanol and dilute alkali respectively. Legume proteins are highly valuable because it has amino acid composition for animals and humans that complements that of cereals. They are deficient in methionine but contain sufficient lysine to overcome its deficiency in cereals (Lajolo and Genovese, 2002; Neus et al., 2005). Relative accumulation of these proteins affects the nutritional and subsequently processing qualities of products.

The use of chemical fertilizers have been increased throughout the world to enhance the production of variety of crops (Abril et al., 2007) but there is persistent nutrient depletion that is posing a greater threat to sustainable agriculture. The continuous use of synthetic chemical fertilizers causes deleterious effects on public health and environment (Pimentel et al., 2005) such as ground and surface water pollution by nitrate leaching (Pimentel and Pimentel, 1996). Loss of nitrogen and ecological contamination due to use of high amounts of N- fertilizer (Iqbal et al., 2012) throughout the world is a major concern these days. Therefore, management methods are required to decrease the usage of chemical fertilizers in order to avoid inverse environmental impacts (Hellal et al., 2014). Nowadays, there is a tremendous increase in global demand for organically grown foods leading to rapid growth in organic agricultural practices. Farmyard manure (FYM) is valuable organic manure that can improve soil health due to its humus, macro- and micro-nutrient contents. Besides helping in improvement of soil structure, aeration and water holding capacity of soil, it can stimulate the microbial activity that enhances number of biological processes improving nutrient uptake (Sarwar et al., 2008). Combined organic/inorganic fertilization enhances carbon storage in soils and reduces nitrogen emissions from fertilizer while contributing high crop productivity in agriculture (Hellal et al., 2014). The objective of this study is to investigate the influence of inorganic (nitrogen and phosphorus) and organic (FYM) fertilizers on storage protein patterns in soybean, chickpea and wheat. 


\section{MATERIALS AND METHODS}

Field Experiments were conducted at fields of Department of Plant Breeding and Genetics, Punjab Agricultural University, Ludhiana in Split Plot Design during Kharif (soybean $\mathrm{Cv}$ SL 525) and Rabi (wheat $\mathrm{Cv}$ PBW343 and chickpea CV PBG1) with four treatments and four replications each during 2011-12 and 2012-13 for two successive years. Soybean was sown in Ist week of June and harvested in last week of October in both years. Wheat and chickpea was sown in midNovember and harvested in mid-March. The treatments included 100\% Organic $\left(\mathrm{T}_{1}\right)$ (Without any chemical or fertilizer): Farmyard manure (FYM @10 tonnes hectare ${ }^{-1}$ ) and spray of neem based insecticides; $100 \%$ Inorganic $\left(\mathrm{T}_{2}\right): 100 \%$ Recommended doses of fertilizer (RDF: $31.25 \mathrm{~kg} \mathrm{~N}+60 \mathrm{~kg} \mathrm{P}_{2} \mathrm{O}_{5}$ hectare $^{-1}$ for soybean, $125 \mathrm{~kg} \mathrm{~N}+62.5 \mathrm{~kg} \mathrm{P}_{2} \mathrm{O}_{5}$ hectare $^{-1}$ for wheat and $15 \mathrm{~kg} \mathrm{~N}+20 \mathrm{~kg} \mathrm{P}_{2} \mathrm{O}_{5}$ hectare $^{-1}$ for chickpea). Recommended herbicides for weeds and insecticides for insect/pest control were used. 50\% Organic $+50 \%$ Inorganic $\left(\mathrm{T}_{3}\right): 50 \% \mathrm{NP}$ recommended dose combined with $50 \%$ dose of Farmyard manure and Integrated nutrient management $\left(\mathrm{T}_{4}\right): 100 \% \mathrm{NP}$ recommended dose combined with $100 \%$ dose of Farmyard manure. The nutrient composition of farmyard manure (oven dry) was $\mathrm{N}(1 \%), \mathrm{P}_{2} \mathrm{O}_{5}(1.5 \%)$ and $\mathrm{K}_{2} \mathrm{O}(1.5 \%)$. Soil $(0$ $-15 \mathrm{~cm}$ depth) was sandy loam in texture with $\mathrm{pH} 8.5$ and was low in organic carbon $(0.12 \%)$, phosphorus and $\mathrm{K}$ (15 and $126 \mathrm{~kg} / \mathrm{ha}$, respectively). The available
$\mathrm{Fe}, \mathrm{Cu}, \mathrm{Mn}$ and $\mathrm{Zn}$ in experimental soil were 2.29, $0.10,4.71$ and $0.97 \mathrm{mg} \mathrm{kg}^{-1}$, respectively. Soybean and chickpea seeds and wheat grains were collected at maturity and storage protein quality of seeds/grains was determined.

Total seed proteins were extracted from defatted seed powder with extraction buffer containing $125 \mathrm{Mm}$ Tris -Hcl buffer ( $\mathrm{pH} 6.8$ ), 4\% sodium dodecyl sulfate (w/v), $20 \%$ glycerol $(\mathrm{v} / \mathrm{v})$ and $0.03 \mathrm{mM}$ bromophenol blue and $50 \mu \mathrm{l}$ of 2 -mercaptoethanol. Total soluble protein of extracts was evaluated by the method of Lowry et al. (1951).

Electrophoresis (SDS-PAGE) was carried out according to the standard procedure (Laemmli, 1970) in 1.5 $\mathrm{mm}$ thick gels with $12.5 \%(\mathrm{w} / \mathrm{v})$ separating gel and $5 \%$ $(\mathrm{w} / \mathrm{v})$ stacking gel. Ten microlitres of ready to use protein markers (GeNei) were applied along with the test samples in a separate well. Hundred $\mu \mathrm{g}$ of each sample was loaded on the gel and electrophoresis was carried out at constant current of $1.5 \mathrm{~mA}$ per well at room temperature using GeNei electrophoretic assembly. Quantitative assessment of relative protein content was made by computer assisted densitometry using the Quantity-one Software (BioRad), and protein was reported in relative amounts per gel.

Statistical analysis: Statistical analysis of various nutrients in all the crops with different organic and inorganic farming conditions were studied using CRD $(\mathrm{p}<0.05$, ANOVA- Analysis Of Variance) using computer application CPCS-1.

Table 1. Effect of organic and inorganic farming conditions on average relative quantity (\%) of storage protein subunits in soybean seeds in year 2011 and 2012.

\begin{tabular}{|c|c|c|c|c|c|c|c|c|c|}
\hline \multirow{2}{*}{ Treatment } & LOX & $\alpha^{\prime}$ & $\alpha$ & $\beta$ & Acidic & Basic & $7 \mathrm{~S}$ & $11 \mathrm{~S}$ & $11 \mathrm{~S} / 7 \mathrm{~S}$ \\
\hline & \multicolumn{9}{|c|}{ Year 2011} \\
\hline FYM@10tha ${ }^{-1}$ & $5.92 \pm 0.21$ & $6.08 \pm 0.14$ & $3.98 \pm 0.49$ & $5.70 \pm 0.27$ & $26.32 \pm 4.77$ & $19.36 \pm 0.10$ & 15.76 & 45.68 & 2.90 \\
\hline $\mathrm{RDF}\left(31.25 \mathrm{~kg} \mathrm{~N}+60 \mathrm{~kg} \mathrm{P}_{2} \mathrm{O}_{5} \mathrm{ha}^{-1}\right)$ & $7.27 \pm 0.01$ & $10.67 \pm 0.30$ & $5.23 \pm 0.42$ & $6.67 \pm 0.24$ & $24.19 \pm 1.01$ & $17.62 \pm 0.23$ & 22.57 & 41.81 & 1.85 \\
\hline FYM@ @ 5 ha $^{-1}+50 \%$ RDF & $6.29 \pm 1.49$ & $11.31 \pm 0.44$ & $5.35 \pm 0.01$ & $7.14 \pm 0.09$ & $24.59 \pm 2.09$ & $17.91 \pm 0.69$ & 23.80 & 42.50 & 1.79 \\
\hline FYM@10tha ${ }^{-1}+100 \%$ RDF & $7.50 \pm 0.14$ & $6.75 \pm 0.32$ & $4.64 \pm 0.54$ & $6.40 \pm 1.33$ & $27.96 \pm 6.92$ & $17.28 \pm 2.68$ & 17.79 & 45.24 & 2.54 \\
\hline \multirow[t]{2}{*}{$\mathrm{CD}(\mathrm{p}<0.05)$} & NS & 0.88 & NS & NS & NS & NS & & & \\
\hline & \multicolumn{9}{|c|}{ Year 2012} \\
\hline$\overline{\text { FYM@10tha }}{ }^{-1}$ & $5.37 \pm 0.55$ & $6.55 \pm 0.13$ & $3.06 \pm 0.06$ & $4.49 \pm 0.28$ & $31.76 \pm 4.82$ & $18.42 \pm 8.51$ & 14.10 & 50.18 & 3.56 \\
\hline $\mathrm{RDF}\left(31.25 \mathrm{~kg} \mathrm{~N}+60 \mathrm{~kg} \mathrm{P}_{2} \mathrm{O}_{5} \mathrm{ha}^{-1}\right)$ & $6.73 \pm 1.99$ & $9.55 \pm 2.95$ & $3.86 \pm 0.01$ & $4.79 \pm 0.90$ & $26.06 \pm 4.31$ & $23.14 \pm 0.18$ & 18.20 & 49.20 & 2.70 \\
\hline FYM@ $9 t_{h a}^{-1}+50 \%$ RDF & $6.27 \pm 1.20$ & $8.66 \pm 1.77$ & $2.63 \pm 0.02$ & $3.62 \pm 0.34$ & $32.96 \pm 3.25$ & $23.75 \pm 1.95$ & 14.90 & 56.71 & 3.81 \\
\hline FYM@10tha ${ }^{-1}+100 \%$ RDF & $5.78 \pm 0.54$ & $8.97 \pm 3.37$ & $2.55 \pm 0.01$ & $2.15 \pm 0.01$ & $32.30 \pm 14.79$ & $20.11 \pm 6.49$ & 13.70 & 52.41 & 3.83 \\
\hline $\mathrm{CD}(\mathrm{p}<0.05)$ & NS & NS & NS & NS & NS & NS & & & \\
\hline
\end{tabular}

Table 2. Effect of organic and inorganic farming conditions on average relative quantity (\%) of storage proteins of chickpea seeds.

\begin{tabular}{|c|c|c|c|c|c|c|c|c|}
\hline \multirow[t]{2}{*}{ Treatment } & \multicolumn{2}{|c|}{ Legumins (kDa) } & \multicolumn{3}{|c|}{ Vicillins (kDa) } & \multicolumn{3}{|c|}{$\begin{array}{c}\text { Legumin Vicillins } \\
11 \mathrm{~S} / 7 \mathrm{~S}\end{array}$} \\
\hline & $\alpha(38-40)$ & $\beta(22-23)$ & 50.7 & $33.6-35.0$ & $15.5-18.9$ & (11S) & (7S) & ratio \\
\hline FYM@10t ha ${ }^{-1}$ & $27.68 \pm 1.05$ & $18.68 \pm 9.02$ & $5.29 \pm 1.8510 .52 \pm 1.80$ & $14.53 \pm 4.34$ & $4.09 \pm 2.93$ & 46.36 & 34.43 & 1.35 \\
\hline $\begin{array}{l}\mathrm{RDF}(31.25 \mathrm{~kg} \\
\left.\mathrm{N}+60 \mathrm{~kg} \mathrm{P}_{2} \mathrm{O}_{5} \mathrm{ha}^{-1}\right)\end{array}$ & $29.11 \pm 0.42$ & $15.19 \pm 3.90$ & $5.33 \pm 2.116 .32 \pm 4.71$ & $9.38 \pm 0.07$ & $6.42 \pm 0.01$ & 44.3 & 27.45 & 1.61 \\
\hline $\begin{array}{l}\text { FYM @ } 9 \mathrm{t} \mathrm{ha}^{-1}+50 \% \\
\text { RDF }\end{array}$ & $23.17 \pm 1.68$ & $27.39 \pm 0.65$ & $4.10 \pm 0.069 .67 \pm 0.02$ & $17.17 \pm 2.62$ & $3.34 \pm 0.02$ & 50.56 & 34.28 & 1.47 \\
\hline $\begin{array}{l}\text { FYM @ } 10 \mathrm{tha}^{-1}+ \\
100 \% \text { RDF }\end{array}$ & $22.55 \pm 1.12$ & $25.14 \pm 5.26$ & $3.77 \pm 0.139 .50 \pm 0.33$ & $18.87 \pm 0.38$ & $4.06 \pm 2.77$ & 47.69 & 36.20 & 1.32 \\
\hline $\mathrm{CD}(\mathrm{p}<0.05)$ & 3.21 & NS & NS & NS & NS & & & \\
\hline
\end{tabular}


Table 3. Effect of organic and inorganic farming conditions on average relative quantity of storage proteins of wheat grains.

\begin{tabular}{|c|c|c|c|c|c|}
\hline \multirow{2}{*}{$\begin{array}{c}\text { Molecular band } \\
\text { (kDa) }\end{array}$} & \multicolumn{4}{|c|}{ Relative quantity } & \multirow{2}{*}{$\begin{array}{c}\text { Critical } \\
\text { Difference }(p<0.05)\end{array}$} \\
\hline & $T_{1}$ & $T_{2}$ & $T_{3}$ & $\mathbf{T}_{4}$ & \\
\hline 90.4 & $4.50 \pm 0.21$ & $4.57 \pm 0.14$ & $4.99 \pm 0.03$ & $4.96 \pm 0.68$ & NS \\
\hline 80.8 & $3.56 \pm 0.08$ & $3.64 \pm 0.12$ & $3.55 \pm 0.01$ & $3.73 \pm 0.10$ & NS \\
\hline 71.8 & $4.40 \pm 0.04$ & $4.36 \pm 0.16$ & $4.70 \pm 0.03$ & $4.78 \pm 0.06$ & 0.24 \\
\hline 61.4 & - & - & $1.39 \pm 0.01$ & $3.73 \pm 0.04$ & 0.06 \\
\hline 55.7 & $3.26 \pm 0.44$ & $2.84 \pm 0.03$ & - & $3.73 \pm 0.28$ & 0.73 \\
\hline 48.8 & $2.91 \pm 0.20$ & $3.22 \pm 0.25$ & $1.58 \pm 0.04$ & $6.75 \pm 0.16$ & 0.50 \\
\hline 40.7 & $6.85 \pm 0.01$ & $7.34 \pm 0.28$ & $6.86 \pm 0.47$ & $4.10 \pm 0.78$ & 1.33 \\
\hline 34.7 & $2.96 \pm 1.80$ & $3.98 \pm 0.91$ & $1.56 \pm 0.04$ & - & NS \\
\hline 30.6 & $4.84 \pm 0.25$ & $5.28 \pm 0.03$ & $5.01 \pm 0.50$ & $4.87 \pm 0.16$ & NS \\
\hline 28.3 & $2.72 \pm 0.12$ & $2.66 \pm 0.05$ & $2.61 \pm 0.03$ & $2.38 \pm 0.28$ & NS \\
\hline 25.2 & $5.87 \pm 0.25$ & $5.35 \pm 1.29$ & $4.90 \pm 0.20$ & $5.21 \pm 0.14$ & NS \\
\hline 22.8 & - & - & $3.36 \pm 0.01$ & $3.34 \pm 0.13$ & 0.19 \\
\hline $18-20$ & $15.08 \pm 0.86$ & $16.67 \pm 1.49$ & $13.69 \pm 0.27$ & $12.35 \pm 2.74$ & NS \\
\hline 16.4 & $4.29 \pm 0.28$ & $3.57 \pm 0.00$ & - & - & NS \\
\hline $11-13$ & $6.45 \pm 0.38$ & $5.89 \pm 1.32$ & $8.82 \pm 0.77$ & $9.96 \pm 1.17$ & 2.72 \\
\hline
\end{tabular}

$\mathrm{T}_{1}=\mathrm{FYM} @ 10 \mathrm{t} \mathrm{ha}^{-1} ; \mathrm{T}_{2}=$ Recommended dose of NP $; \mathrm{T}_{3}=\mathrm{FYM} @ 5 \mathrm{t} \mathrm{ha}^{-1}+50 \%$ recommended dose of NP; $\mathrm{T}_{4}=\mathrm{FYM} @ 10 \mathrm{t}$ $\mathrm{ha}^{-1}+100 \%$ recommended dose of NP

\section{RESULTS AND DISCUSSION}

Electrophoretic studies followed by densitometric analysis revealed significant variations in relative quantity of $\alpha^{\prime}$ subunit of $\beta$-conglycinin protein in soybean seeds among different treatments in year 2011 (Table 1). The relative quantity of $\alpha$ and $\beta$ subunits of $\beta$-conglycinin and glycinin proteins in soybean seeds in years 2011 and 2012 did not vary significantly among various treatments (Table 1). Highest value of glycinin to $\beta$-conglycinin ratio in soybean seeds in year 2011 and 2012 was observed in treatment with FYM@10t ha ${ }^{-1}$ and in FYM @ 10t ha ${ }^{-1}+100 \%$ RDF, respectively. Khaim et al.(2013) found that quality of soybean is enhanced by the combined treatment of organic manure and recommended dose of chemical fertilizers. The major storage proteins in soybean are $11 \mathrm{~S}$ glycinin and $7 \mathrm{~S}$ conglycinins. Glycinin is composed of five subunits viz., acidic, basic A3A5whose concentration of S-amino acids ranges from $3 \%$ to $4.5 \%$ (Fukushima, 1991). $\beta$-conglycinin is

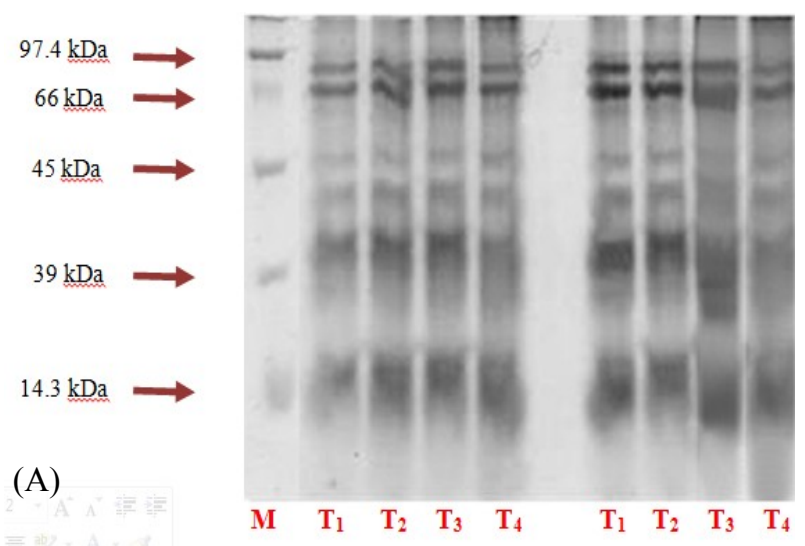

composed of three non-identical subunits, $\alpha, \alpha^{\prime}, \beta$ with a molecular weight (Mr) of 76, 72, and $53 \mathrm{kDa}$ respectively (Fig. 1). It contains less than $1 \% \mathrm{~S}$-containing amino acids (Sebastiani et al., 1990) and the $\beta$ - subunit of $\beta$-conglycinin contains only one cysteine residue and no methionine. Ratio of glycinin to $\beta$-conglycinin proteins is an indicator of protein quality, greater the ratio, greater the concentration of methionine and cysteine per unit protein and better the quality of the storage protein (Wang et al., 2008). The nonsignificant changes in $11 \mathrm{~S} / 7 \mathrm{~S}$ ratio among different treatments suggest no change in storage protein quality of soybean seeds under organic or inorganic farming conditions.

In chickpea, legumins and vicillins are the major storage proteins amounting to $\%$ of total protein content. Chickpea legumins are made up of $\alpha$ and $\beta$ subunits with approximately molecular weight of 3840 and $22-23 \mathrm{kDa}$, respectively. Vicillins contains four subunits with approximately molecular weight 70,51 ,

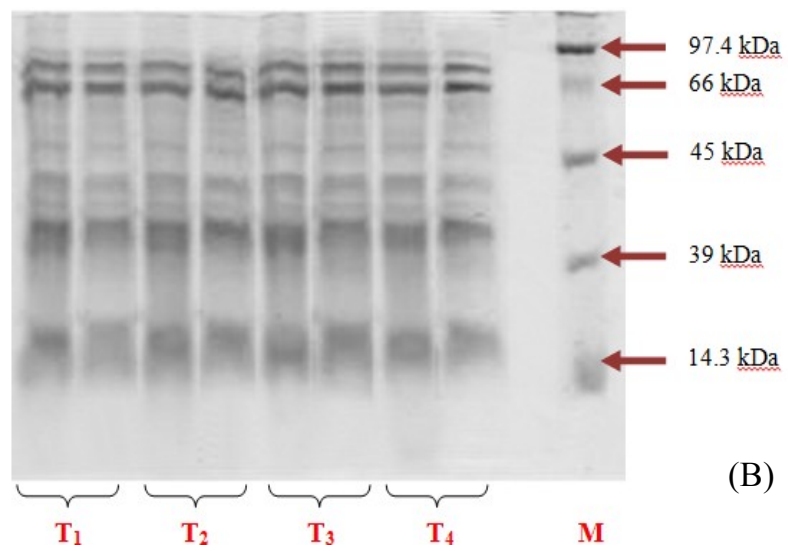

Fig. 1. Effect of organic and inorganic farming conditions on protein subunit banding patterns of soybean seeds in year (A) 2011 and (B) 2012. $\mathrm{T}_{1}=F Y M @ 10 t \mathrm{ha}^{-1} ; T_{2}=$ Recommended dose of NP; $T_{3}=F Y M @ 5 t h a^{-1}+50 \%$ recommended dose of NP; $T_{4}=$ FYM@10t ha $\mathrm{a}^{-1}+100 \%$ recommended dose of NP 

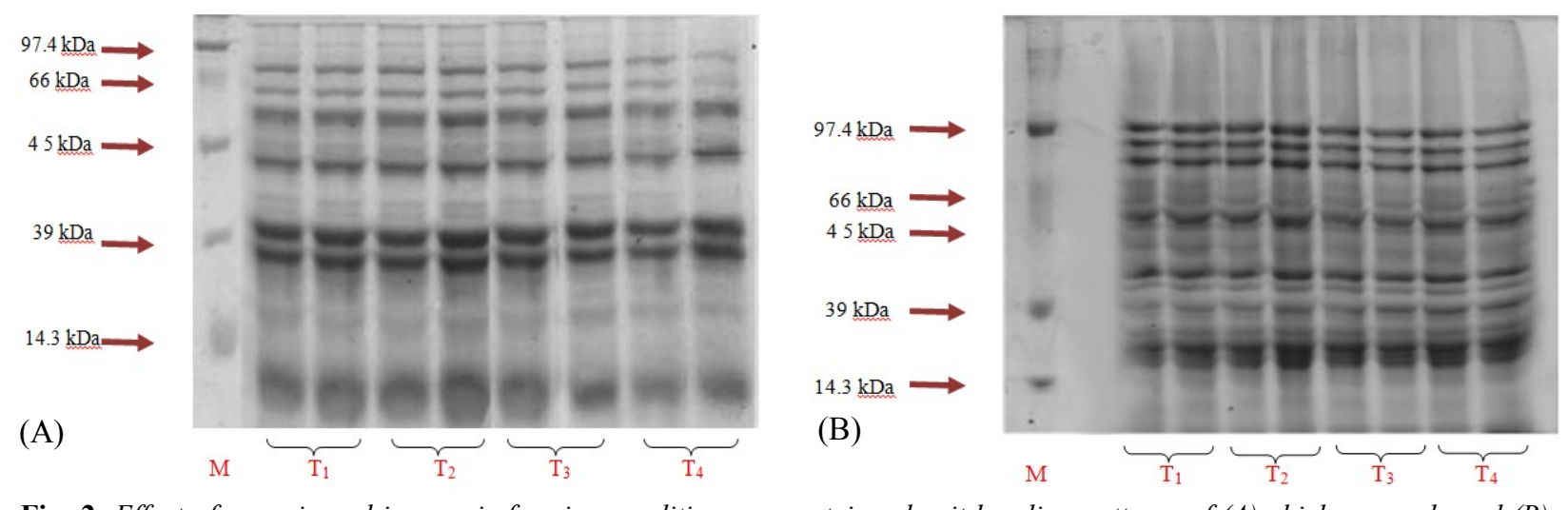

Fig. 2. Effect of organic and inorganic farming conditions on protein subunit banding patterns of (A) chickpea seeds and (B) wheat grains. $T_{1}=F Y M @ 10 t h a^{-1} ; T_{2}=$ Recommended dose of $N P ; T_{3}=F Y M @ 5 t h a^{-1}+50 \%$ recommended dose of $N P ; T_{4}=$ FYM@10tha -1 $^{-1}$ 100\% recommended dose of NP

35 and $18 \mathrm{kDa}$ (Fig. 2A). The relative quantity of $\alpha$-subunit of legumins showed significant changes among different treatments whereas \% values of other subunits of legumins and vicillins did not vary significantly (Table 2). The relative proportion of $\alpha$ subunit of legumin fraction was statistically similar in treatments with organic and inorganic fertilizer but the values were significantly lower $(p<0.05)$ when combined treatment of FYM + RDF was applied. Highest value of legumins to vicillins ratio was observed in treatment with recommended dose of NP. SDS-PAGE analysis of wheat grain storage proteins revealed a total of 15 bands on electrophotogram (Table 3, Fig. 2B). The polypeptides with molecular weight between $30-45 \mathrm{kDa}$ belong to $\alpha, \beta$ and $\gamma$ subunits of gliadin which are S-rich proteins consisted of three bands. The group of polypeptides with molecular weight of about 55-75 $\mathrm{kDa}$ is S-poor subunits of gliadin or $\omega$-gliadins. $\omega$-gliadin subunits consisted of three polypeptides with molecular weight 55, 62 and $72 \mathrm{kDa}$. Besides major protein subunits polypeptides with molecular weight of $90.4,80.8,28.3,25.2,22.8$, 18-20 kDa, 16.4 and between 11-13 kDa were also detected on SDS-PAGE. The protein banding pattern was similar to earlier studies by Zilic et al. (2011) who have characterized proteins from grains of different bread and durum wheat genotypes. The bands corresponding to 61.4 and $22.8 \mathrm{kDa}$ were not observed when FYM @ 10t ha ${ }^{-1}$ or RDF was applied. But combined treatments of organic and inorganic fertilizer resulted in presence of bands corresponding to 61.4 and $22.5 \mathrm{kDa}$ but disappearance of subunit band corresponding to $16.4 \mathrm{kDa}$. The relative quantity of subunit bands with molecular weight 55.7 and $48.8 \mathrm{kDa}$ was significantly higher in treatment with FYM @ $10 \mathrm{tha}^{-1}$ $+100 \% \mathrm{RDF}$ as compared to when these treatments were applied alone, whereas $40.7 \mathrm{kDa}$ band showed significantly low relative quantity in treatment of FYM (a) $10 \mathrm{t} \mathrm{ha}^{-1}+100 \%$ recommended dose of NP as compared to other treatments. Protein subunit bands with molecular weight range from 11-13 $\mathrm{kDa}$ were low in relative quantity in organic or inorganic treatments as compared to their combined treatment (Table 3). Significant influence of organic and conventional ways of growing on wheat storage protein quantity has been reported. Higher crude protein, wet gluten and yield in wheat varieties from conventional growing whereas wheat varieties from organic growing were mainly characterized by significantly higher percentage of albumins and globulins (Krejcirova et al., 2007; Nitika et al., 2008). Genotype influenced the amount and size distribution of polymeric proteins in organically grown wheat (Hussain et al., 2009). Amount of gluten increased after compost treatment, thus indicating positive effects in quality of wheat flour (Gopinath et al., 2008). In contrary to this it has been reported that organic fertilization resulted in production of less protein in cereal grains (Starling and Richards, 1993; Worthington, 2001; Langenkamper et al., 2006) that may be due to lower amounts of nitrogen in organically managed soils. Except for nitrate content, there was no strong evidence for difference in concentration of nutrients in organic and conventional foods (Bourn and Prescott, 2002). No significant difference was reported in crude protein and moisture between 9 samples of wheat grown organically and conventionally on different farms (Shier and Kelman, 1984). Protein content was negatively influenced by organic farming but didn't influence the technological performance of bread wheat (Triticum aestivum L.) (Carcea and Salvatorelli, 2006; Mader et al., 2007). The milling performance was similar between organic and conventional samples whereas volume of organic loaves of bread was significantly lower than those of corresponding conventional ones.

\section{Conclusion}

It was concluded from present studies that use of combined treatments of Farm yard manure and recommended doses of nitrogen and phosphorus fertilizers does not change storage protein quality of soybean, chickpea and wheat in a soybean based cropping system under climatic conditions of Punjab and so can be used to improve fertilizer management practices. 


\section{REFERENCES}

Abril, A., Baleani, D., Casado-Murillo, N. and Noe, L. (2007). Effect of wheat crop fertilization on nitrogen dynamics and balance in the humid Pampas, Argentina. Agric. Ecosys. Environ. 119: 171-176.

Bourn, D. and Prescott, J. (2002). A comparison of the nutritional value, sensory qualities and food safety of organically and conventionally produced foods. Crit. Rev. Food Sci. Nutr. 42: 1-34.

Carcea, M. and Salvatorelli, S. (2006). Influence of growing conditions on the technological performance of bread wheat (Triticum aestivum L.). Int. J Food Sci. Tech. 41:102-107.

Fukushima, D. (1991). Recent progress of soybean protein foods: chemistry, technology and nutrition. Food Rev. 7: 323-351.

Gopinath, K.A., Saha, S., Mina, B. L., Pande, H., Kundu, S. and Gupta, H. S. (2008). Influence of organic amendments on growth, yield and quality of wheat and on soil properties during transition to organic production. Nutr. Cycl. Agroecosys. 82: 51-60.

Hellal, F.A., Zewainy, R.M., Khalil, A.A. and Ragab, A.A.M. (2014). Effect of organic and bio-fertilizer management practices on nutrient availability and uptake by Faba bean-Maize sequence. American-Eurasian J Sustain. Agric. 8: 35-42.

Hussain, A., Larsson, H., Kuktaite, R., Prieto-Linde, M.L. and Johansson, E. (2009). Protein content and composition in organically grown wheat: Influence of genotype. Agron. Res. 7: 599-605.

Iqbal, M., Khan, A.G., Hassan, A.U. and Amjad, M. (2012). Soil physical health indices, soil organic carbon, nitrate contents and wheat growth as influenced by irrigation and nitrogen rates. Int. J Agric. Bio. 14: 1-10.

Khaim, S., Chowdhury, M. A. H. and Saha, B. K. (2013). Organic and inorganic fertilization on the yield and quality of soybean. J. Bangladesh Agril. Univ. 11(1): 23-28.

Krejcirova, L., Capouchova, I., Petr, J., Bicanova, E. and Famer (2007). The effect of organic and conventional growing systems on quality and storage protein composition of winter wheat. Plant Soil Environ. 53: 499-505.

Laemmli, U.K. (1970). Cleavage of structural proteins during the assembly of the head of bacteriophage $\mathrm{T}_{4} . \mathrm{Na}$ ture. 22: 680-685.

Lajolo, F.M. and Genovese, M.I. (2002). Nutritional significance of lectins and enzyme inhibitors from legumes. $J$ Agric. Food Chem. 50: 6592-6598.

Langenkamper, G., Zorb, C., Seifert, M., Mader, P., Fretzdorff, B. and Betsche, T. (2006). Nutritional quality of organic and conventional wheat. J Appl. Bot. Food
Qual. 80: 150-154.

Lowry, O.H., Rosenbrough, N.J., Farr, A.L. and Randall, R.J. (1951). Protein measurement with Folin phenol reagent. J Bio. Chem. 193: 265-275.

Mader, P., Hahn, D., Dubois, D., Gunst, L., Alfoldi, T., Bergmann, H., Oehme, M., Amado, R., Schneider, H., Graf, U., Velimirov, A., Fliessbach, A. and Niggli, U. (2007). Wheat quality in organic and conventional farming: results of a 21 year field experiment. $J$ Food Agric. 87: 1826-1835.

Neus, J.D., Fehr, W.F. and Schnebly, S.R. (2005). Agronomic and seed characteristics of soybean with reduced raffinose and stachyose. Crop Sci. 45: 589-592.

Nitika, Punia, D. and Khetarpaul, N. (2008). Physiochemical characteristics, nutrient composition and consumer acceptability of wheat varieties grown under organic and inorganic conditions. Int. J Food Sci. Nutr. 59: 224-245.

Pimentel, D. and Pimentel, M. (1996). Food, Energy and Society. Niwot: Colorado University Press.

Pimentel, D., Hepperl, P., Hanson, J., Douds, D. and Seidel, R. (2005). Environmental, Energetic and Economic comparisons of organic and conventional farming system. Bio Sci. 55: 573-582.

Sarwar, G., Hussain, N., Schmeisky, H., Muhammad, S., Ibrahim, M. and Safdar, E . (2008). Improvement of soil physical and chemical properties with compost application in rice-wheat cropping system. Pak.J Bot. 40: 275-282.

Sebastiani, F.L., Farrell, L.B., Schuler, M.A. and Beachy, R.N. (1990). Complete sequence of cDNA of a subunit of $\beta$-conglycinin. Plant Mol. Bio. 15: 197-201.

Shier, N.W. and Kelman, J. (1984). A comparison of crude protein, moisture, ash and crop yield between organic and conventionally grown wheat. Nutr. Reports Int. 30: 71-76.

Starling, W. and Richards, M.C. (1993). Quality of commercial samples of organically-grown wheat. Aspects Appl. Bio. 36: 205-209.

Wang, S.Y., Chen, C.T., Sciarappa, W., Wang, C.Y. and Camp, M. J. (2008). Fruit quality, antioxidant capacity, and flavonoid content of organically and conventionally grown blueberries. J Agric. Food Chem. 56: 5788-5794.

Worthington, V. (2001). Nutritional quality of organic versus conventional fruits, vegetables and grains. J Altern Complem.Med. 7: 161-173

Zilic, S., Barac, M., Pesic, M., Dodig, D. and IgnjatovicMicic, D. (2011). Characterization of proteins from grain of different bread and durum wheat genotypes. Int.l J Mol. Sci. 12: 5878-5894. 